\title{
Az új típusú koronavírus okozta megbetegedés (COVID-19): összefoglaló hematológusoknak I. - virológia, molekuláris patogenezis és klinikum
}

\author{
Szabó Bálint Gergely ${ }^{1,2,3, @ ~}$, Bobek Ilona ${ }^{1}$, Réti Marienn ${ }^{1}$, Gopcsa László ${ }^{1}$, Mathiász Dóra ${ }^{1}$, \\ Lakatos Botond $^{1}$, Bekő Gabriella ${ }^{1}$, Pető Mónika ${ }^{1}$, Sinkó János ${ }^{1}$, Mikala Gábor ${ }^{1}$, Kis Zoltán ${ }^{3}$, \\ Szlávik János ${ }^{1}$, Reményi Péter ${ }^{1}$, Vályi-Nagy István ${ }^{1}$ \\ ${ }^{1}$ Dél-pesti Centrumkórház, Országos Hematológiai és Infektológiai Intézet (Budapest) \\ ${ }^{2}$ Semmelweis Egyetem, Klinikai Tudományok Doktori Iskola (Budapest) \\ ${ }^{3}$ Nemzeti Népegészségügyi Központ (Budapest)
}

\begin{abstract}
A COVID-19 a SARS-CoV-2 vírus által okozott, járványosan terjedő, légúti kiindulású betegség. A kórokozó magas patogenitású, zoonotikus eredetű humán coronavírus, mely hatékonyan terjed emberről emberre cseppfertőzéssel és közeli kontaktussal. A medián lappangási idő 5 nap, a maximum 14 nap. A COVID-19 kardinális tünetei a láz, dyspnoe és száraz köhögés. Az esetek 80\%-a enyhe lefolyású, 5\%-ban azonban intenzív terápiás ellátás és gépi lélegeztetés válik szükségessé. A COVID-19 akár súlyos, az egész szervezetre kiterjedő citokinvihart is kiválthat, mely gyors beavatkozás nélkül végzetes kimenetelü lehet. Jelen összefoglaló - melyet a diagnosztikai és terápiás szempontokat tárgyaló társközlemény követ - a betegséggel kapcsolatban 2020. május 25-ig elérhető legfőbb nemzetközi és hazai irodalmi eredményeket ismerteti; elsősorban, de nem kizárólag hematológus kollégák számára.
\end{abstract}

Kulcsszavak: COVID-19, SARS-CoV-2, világjárvány, citokinvihar

The novel coronavirus disease (COVID-19): a review for specialists in hematology I - virology, molecular pathogenesis and clinical aspects

COVID-19 is a pandemic infection caused by SARS-CoV-2, a highly pathogenic human coronavirus with zoonotic origin which is efficiently transmitted by air droplets and close contact. The median incubation time is 5 days, with a maximum of 14 days. Cardinal symptoms include fever, dyspnea and dry cough. Despite that $80 \%$ of all cases are mild, $5 \%$ need intensive therapy and ventilatory support during the hospital stay. Although starting in the respiratory tract, COVID-19 could produce an ultimately fatal cytokine storm in certain patients, prompting for novel therapeutic interventions. The present review is the first part of two co-publications aiming to summarize international and Hungarian literature of COVID-19 as of May 25, primarily but not exclusively for specialists in hematology.

Keywords: COVID-19, SARS-CoV-2, pandemic, cytokine storm

(Beérkezett: 2020. június 1.; elfogadva: 2020. június 15.)

@ Levelezési cím: Dr. Szabó Bálint Gergely, Dél-pesti Centrumkórház, Országos Hematológiai és Infektológiai Intézet, 1097 Budapest, Albert Flórián út 5-7., Tel.: 06-1/455-8100/8469 


\section{Rövidítések}

ACE2 - angiotenzin-konvertáló enzim 2 (angiotensin converting enzyme 2 receptor); ADE - antitestdependens erősítés (antibody dependent enhancement); ARDS - akut légzési distressz szindróma (acute respiratory distress syndrome); AZI - azithromycin; $\mathrm{BAL}$ - bronchoalveolaris lavázs (broncholalveolar lavage); $\mathrm{CD}$ - differenciációs klaszter (cluster of differentiation); CMIE - kemolumineszcens mikropartikulum immunoassay (chemiluminescent microparticle immunoassay); COVID-19 - coronavírus betegség-19 (coronavirus disease-19); CQ - chloroquin; CRS - citokinfelszabadulási szindróma (cytokine release syndrome); DAD - diffúz alveoláris károsodás (diffuse alveolar damage); DIC - disszeminált intravaszkuláris koaguláció (disseminated intravascular coagulation); ELISA - enzimhez kötött immunoszorbens assay (enzyme-linked immunosorbent assay); ER - endoplazmatikus retikulum (endoplasmatic recitulum); $\mathrm{FiO}_{2}$ - belégzési $\mathrm{O}_{2}$-frakció (fraction of inspired oxigen); FVP - favipiravir; HAP egészségügyi ellátással összefüggő pneumonia (healthcare-acquired pneumonia); HLH - haemophagocytás lymphohistiocytosis (haemophagocytic lymphohystiocytosis); HMPV - humán metapneumovírus (human metapneumovirus); HCQ - hidroxychloroquin; ICU - intenzív terápiás osztály (intensive care unit); IFN - interferon (interferon); IPA - invazív tüdőaspergillosis (invasive pulmonary aspergillosis); IVIG - intravénás immunglobulin; $\mathrm{LPV} / \mathrm{r}$ - lopinavir/ritonavir; MAS - macrophag aktivációs szindróma (macrophag activation syndrome); MBL - mannózkötő lektin (mannose binding lectin); MSC - mesenchymalis őssejt (mesenchymal stem cell); NK - természetes ölősejt (natural killer); MERS-CoV - közel-keleti légzőszervi szindróma coronavírus (Middle Eastern Respiratory Syndrome Coronavirus); $\mathrm{PaO}_{2}$ - artériás parciális $\mathrm{O}_{2}$-tenzió (partial pressure of $\mathrm{O}_{2}$ ); PCR - polimeráz láncreakció (polymerase chain reaction); $\mathrm{R}_{0}$ - elemi reprodukciós szám (basic reproduction number); RBD - receptorkötő domén (receptor binding domain); RDV - remdesivir; RNS - ribonukleinsav (ribonucleic acid); RSV - légzőszervi szinciciális vírus (respiratory syncytial virus); RT-PCR - valós idejü polimeráz láncreakció (real time PCR); SARS - súlyos akut légzőszervi szindróma (severe acute respiratory syndrome); SARS-CoV-1 - súlyos akut légzőszervi szindróma coronavírus-1 (Severe Acute Respiratory Syndrome Coronavirus-1); SARS-CoV-2 - súlyos akut légzőszervi szindróma coronavírus-2 (Severe Acute Respiratory Syndrome Coronavirus-2); SIRS - szisztémás gyulladásos válaszrekació szindróma (systemic inflammatory response syndrome); $\mathrm{SpO}_{2}-$ perifériás $\mathrm{O}_{2}$-szaturáció (peripheral saturation of $\mathrm{O}_{2}$ ); TMPRSS2 - transzmembrán szerin-proteáz 2 (transmembrane protease, serine 2); VAP - lélegeztetéssel összefüggő pneumonia (ventilator-associated pneumonia); VTM - vírustranszport-médium (virus transport medium); WHO - Egészségügyi Világszervezet (World Health Organization)

\section{Bevezetés}

„Betegségem március utolsó péntekén kezdődött kifáradással, mellkasi fájdalommal, köhögéssel, rekedtséggel. Mivel klinikusként dolgozom, mintát vettem magamtól coronavírus PCR-re, sejtve a bajt. Másnap reggel magas lázzal, a fejtetőtöl lábujjamig, korábban sosem tapasztalt fájdalommal, szemlüktetéssel ébredtem. Délután megtörten hivott egy kollégám, hogy a PCR az eddigi egyik legmagasabb kópiaszámmal erôsen pozitív eredményt adott - igy váltam új típusú coronavirus betegségben szenvedö statisztikai esetté. A betegség elsö négy napjára alig emlékszem: ezeket átaludtam lázzal és fájdalommal. Négy nap után már keveset tudtam mozogni és enni, a láz valamelyest szelídült, de a fájdalom és a légúti tünetek megmaradtak. Orvosként a legnagyobb pszichés terhet a kiszámithatatlan jövö, a progresszió bekövetkeztére legvalószinübb 7-10. nap jelentette, gyakori láz-és szaturációmérésekkel. Összesen 3 hétig voltam beteg, utoljára a magas höemelkedés múlt el." (Egy megbetegedett orvos beszámolójából.)

A COVID-19 (coronavirus disease-19) a SARS-CoV-2 (severe acute respiratory syndrome-coronavirus-2) magas patogenitású humán coronavírus által okozott akut, légúti kiindulású betegség. A COVID-19 első dokumentált esetközlései 2019. decemberében a kínai Vuhanból származnak, ahonnan a vírus járványos terjedésnek indult, majd a világ 185 országába eljutott. A korábbi ázsiai epicentrum később Európára és az USA-ra, majd Oroszországra és Dél-Amerikára tevődött át. Hazánkban a koronavirus.gov. $h u$ oldal információi alapján a betegség közösségi és újabban nozokomiális terjedést mutat. A kézirat lezártáig az igazolt esetek száma meghaladta a 3700-at, az elhunytaké pedig a 480 -at.

Jelen összefoglalásunk az első azon két társközlemény közül, melyek célja, hogy a 2020. május 25 -ig elérhető hazai és nemzetközi irodalmi adatok alapján ismertesse a COVID-19-cel kapcsolatos legfontosabb tudnivalókat elsősorban, de nem kizárólag a hematológus olvasók számára. Ennek kapcsán tárgyalásra kerül a fertőzés klinikai virológiája, molekuláris szintű patogenezise, és annak a klinikai lefolyással fennálló kapcsolata. A közleményben kitérünk a malignus hematológiai betegségben szenvedöket érintő speciális klinikai szempontokra is.

A közlemények nem tárgyalják a COVID-19 epidemiológiáját, a részletes járványügyi teendôket, a gyermekkori COVID-19 sajátosságait, valamint a betegséggel kapcsolatos általános tudnivalókat. További tájékozódás céljából ajánljuk az Orvostovábbképző Szemlében megjelent, on-line, szabadon hozzáférhető összefoglalót (Szabó Bálint Gergely: „Egy új világjárvány közepén - amit eddig a COVID-19-ról tudni vélünk"), valamint javasoljuk a COVID-19-cel kapcsolatos aktuális magyar eljárásrend áttekintését az nnk.gov.hu oldalon [1].

A hematológiai betegek ellátásával kapcsolatos speciális teendők betegségenkénti bontásban az American Society of Hematology (www.hematology.org/covid-19) és a European Hematology Association (www.ehaweb.org/covid-19) honlapjain rendszeresen frissítve olvashatóak.

\section{A COVID-19 klinikai virológiája}

\section{A SARS-CoV-2 taxonómiája és morfológiája}

A SARS-CoV-2 (Severe Acute Respiratory Syndrome Coronavirus-2) lipidburokkal rendelkező, pozitív egyszálú 
RNS-vírus, a Coronaviridae család tagja. A coronavírusok nevüket a jellegzetes elektronmikroszkópos képpel rendelkező felszíni glikoproteinről, az S- (spike-) fehérjéről kapták. A családba tartoznak még az immunkompetens gyermekekben és felnőttekben náthának megfelelő klinikai képpel jellemzett felső légúti fertőzést, immunsérültekben esetenként súlyos víruspneumonitist is okozó, ún. alacsony patogenitású humán coronavírusok (OC43, HKU1, 229E, NL63) is. A SARS-CoV-2 korábban azonosított, súlyos alsó légúti fertőzést létrehozni képes, járványosan terjedő, ún. magas patogenitású humán coronavírusokkal (Severe Acute Respiratory Syndrome Coronavirus-1, SARS-CoV-1 és Middle Eastern Respiratory Syndrome Coronavirus, MERS-CoV) mutat rokonságot: filogenetikai analízis alapján a SARS-CoV-1 és SARS-CoV-2 szekvencia homológiája $80 \%$, míg a MERS-CoV és SARSCoV-2 között az azonosság 50\%-os [2].

\section{A SARS-CoV-2 genetikája}

A vírustörzsek genetikai diverzitása és virulenciája közötti kapcsolat nem egyértelmü. Egy korai populációgenetikai analízis felvetette, hogy a SARS-CoV-2 vírustörzsnek egy SNP (single nucleotide polymorphism, egypontos nukleotid-polimorfizmus) mentén „szerin” (S) illetve „leucin” (L) irányba mutálódott két különböző variánsa kering Kínában. Feltehetően az utóbbi vírustörzs mutat rapidabb terjedést a humán populációban [3,4]. A járvány későbbi szakaszában, eltérő helyeken élő, különböző súlyosságú tüneteket mutató fertőzöttek klinikai mintáiból izolált 104 törzs teljesgenom-szekvenálásának eredményeként bebizonyosodott, hogy a keringő vírustörzsek 99.9\%-os homológiát mutatnak, anélkül, hogy jelentős mutációkat hordoznának [5, 6]. Pécsi kutatók által végzett genomikai analízis szerint a vírus valószínüleg több nyugat-európai forrásországból, időben párhuzamosan zajló belépések során kerülhetett hazánkba [7].

A közelmúltban végzett vizsgálatok eredményei alapján valószínű, hogy a vírus fertőzőképessége - a SARS-CoV1-hez viszonyítva - az S-proteinen lévő receptorkötő egység (receptor binding domain, RBD) kritikus részének rekombinációja, illetve egy specifikus, új hasítási hely beépülése révén növekedett meg. Az RBD említett kritikus része hat aminosavból áll, ezek közül 5 eltér a SARS-CoV-2 és SARS-CoV-1 között. A SARS-CoV-2 RBD-je a vírus receptoraként szolgáló humán - és azzal jelentős strukturális homológiát mutató állati - angiotenzin-konvertáló enzim 2 (angiotensin converting enzyme 2, ACE2) receptorhoz magasabb affinitással kötődik, így hatékonyabban képes emberről emberre terjedni. Ezen felül a SARSCoV-2 genomjába beilleszkedett egy 4 aminosavat kódoló specifikus nukleinsav-szekvencia is, mely az S-protein alegységei közötti tetrapeptid-szakaszra transzlálódik. A peptidhidat a humán célsejtek egyik endoproteáza, a furin képes hasítani: a folyamat feltehetően elősegíti a vírus felvételét és intracelluláris transzportját. A fenti, humán virulencia vonatkozásában optimális szerkezeti tulajdonságok, valamint az emberi genommanipulációra utaló molekuláris eltérések hiánya tudományos konszenzust eredményezett, mely szerint a SARS-CoV-2-t laboratóriumi körülmények között, mesterségesen létrehozni nem lehetett, az természetes szelekció eredménye [8].

\section{A SARS-CoV-2 zoonotikus eredete}

A fertőzött sejteken 96 óra alatt citopathiás hatást eredményező, infektív SARS-CoV-2 víruspartikulumokat először majom eredetű Vero-E6 sejteken, humán Huh7 és légúti epithelsejteken sikerült tenyészteni. Ezekben a rendszerekben a SARS-CoV-2 citopathiás hatását humán rekonvaleszcens savóval neutralizálni lehetett [2]. A SARS-CoV-2 - más coronavírusokhoz hasonlóan - valószínüleg zoonotikus eredetü: a vírus teljes genomja 96\%-os homológiát mutat a RaTG13 nevü, SARS-szerű denevér coronavírussal. Ez alátámaszthatja a fajok közötti ugrás evolúciós jelentőségét a fertőzési lánc létrejöttében. Kísérleti körülmények között, in vivo, intranasalis inokuláció révén, vadászgörényben és macskában is létre tudtak hozni fertőzést. Polimeráz láncreakcióval (polymerase chain reaction, $\mathrm{PCR}$ ) pozitívnak bizonyuló kísérleti állatokból az infektív SARS-CoV-2 partikulumokat pedig sikerült újra kitenyészteni. Elképzelhető, hogy a SARS-CoV-2 (pl. a tevékben enzootikus MERS-CoVhoz hasonlóan) az állatvilágban is képes rezervoár(oka)t kialakítani, és mindeddig nem azonosított, intermedier gazdaállatok közvetítésével a humán és állati populációk között cirkulálni [9].

\section{A SARS-CoV-2 transzmissziója}

A vírus elsődlegesen cseppfertőzéssel, valamint direkt (pl. közeli, tartós érintkezés a beteggel) és indirekt (pl. közeli, tartós érintkezés a beteg kontaminált használati tárgyaival) kontaktus révén terjed hatékonyan emberről emberre. A sikeres cseppfertőzés valószínüsége az expozíció körüli 2 méteres távolságon belül a legmagasabb, az infektív makropartikulákat köhögés, tüsszentés és szokásos hangerejü beszéd is továbbíthatja. A fertőző inokulum küszöbértéke egyelőre nem ismert, azonban az átvitel hatékonyságát a magas légúti víruskópiával rendelkező tünetes beteggel való közeli, tartós - főként védőfelszerelés nélküli - expozíció nagyban elősegíti [10,11].

In vitro vizsgálatok alapján a vírus szobahőmérsékleten, fizikokémiai behatás (pl. fertőtlenítőszer, sugárzás stb.) alkalmazása nélkül, müanyag és acél felszíneken akár 3 napig, kartonpapíron egy napig, rézfelszínen 4 órán keresztül is fertőzőképes maradhat. Hasonló próbák során bizonyították, hogy a SARS-CoV-2 aeroszolizált folyadékban órákig fennmaradt, bár ezen eredmények nem bizonyítják, hogy a SARS-CoV-2 a kísérleti elrendezéseken kívül, a való életben is hatékonyan terjedne aeroszollal. A vírus RNS-ének jelenlétét igazolták tünetes betegek szérumából, nyálából, ondójából, anyatejéből és vizeletéből. Kimutatták továbbá tünetes és rekonvaleszcens bete- 
gek székletmintáiból is. A fertőzés járványos transzmiszsziójában ugyanakkor a fekális-orális, fekális-légúti, szexuális és anyatejjel történő átvitel szerepe valószerütlen. Intrauterin és transzplacentáris transzmisszióra nincs bizonyíték. Viszonylag új adat, hogy a vírus valószínüleg fertőzni képes jelentős conjunctivalis expozíció során. A fertőzés dinamikájának megértése szempontjából fontos tudnunk, hogy bármely testnedvből vagy szövetből történő virális RNS kimutathatósága nem azonos a beteg tényleges fertőzőképességével [11-17].

Úgy tűnik, hogy a tünetes személyek fertőzőképessége a tünet megjelenése utáni 1-4. napon a legkifejezettebb, és az infektivitás a tünetek súlyosságával arányosan nő. Egyes PCR-alapú vizsgálatok során viszont a tünetkezdet napján észlelték a pharyngealis vírusmennyiség tetőzését, mely felveti a megelőző 1-3 napos időszakban az ún. aszimptomatikus terjesztés lehetőségét [18, 19]. Ezzel szemben a World Health Organization (WHO) álláspontja szerint a járvány transzmissziós dinamikájának fenntartói a tünetes betegek, így a tünetmentes emberekről induló közösségi terjedés kockázata nem magas [5]. Jelenleg nem rendelkezünk elegendő bizonyítékkal arra vonatkozóan, hogy tünetmentes személyek a PCR-alapú tesztelésükkor fertőzésre alkalmas koncentrációban ürítenék a víruspartikulumokat. A kérdés egyértelmű megválaszolását nehezíti, hogy a mintavételkor tünetmentes emberek 80\%-a 1-2 napon belül tünetessé válik, így helyesebb preszimptomatikus fertőzőképességről beszélni [10]. Az eddig megjelent közlemények szerint az aszimptomatikus/preszimptomatikus fázisban lévő emberek valószínűleg akkor jelenthetnek járványügyi szempontból releváns expozíciós veszélyt, ha nagy számú személlyel kerülnek tartós-közeli kontaktusba, mivel ez lokális terjedés beindulását eredményezheti (pl. egészségügyi dolgozó családjában, zsúfolt szociális otthonban) [20, 21].

A klasszikus epidemiológiából ismert, ún. elemi reprodukciós szám $\left(\mathrm{R}_{0}\right)$ azt fejezi ki, hogy egy típusos fertőzött beteg, hatékony expozíció során, fogékony populációban, járványügyi intervenciók nélkül átlagosan hány másik embert képes megfertőzni. A SARS-CoV-2 medián $\mathrm{R}_{0}$ értékét kínai adatokon alapuló modellekben 2,79-nek kalkulálták $(1,4-3,9)$, vagyis a fenti kritériumok teljesülése esetén kb. 2-3 új fertőzésre számíthatunk. A kalkulált érték 2-3-szorosa a szezonális influenzáénak, így a SARSCoV-2 terjedése hatékonyabbnak mondható [10, 22]. A 2002 és 2004 között lezajlott SARS-járvány kapcsán figyelték meg, hogy az ún. szuperterjesztők (superspreader) szerepet játszanak a lokális és közösségi transzmisszió fenntartásában. Szuperterjesztő az a tünetes vagy tünetmentes fertőzött, aki az átlagos beteghez képest sokkalta nagyobb valószínüséggel fertőz meg másokat, vagyis a személyhez köthető szekunder esetek száma többszöröse az elemi reprodukciós szám alapján várhatónak. Szuperterjesztés lehetőségét vetheti fel, ha kontaktkutatás révén az érintett populációban adott idő alatt újonnan regisztrált esetek többsége egyetlen személyhez vezethető vissza. Az egyes járványok során, korai adatok birtokában a szu- perterjesztés jelenségének valószínűsége megbecsülhető. A COVID-19 terjedése kapcsán is igazolták szuperterjesztők szerepét. Erre jó példa a Dél-Koreában regisztrált „patient 31", aki egymaga kb. 14 nap leforgása alatt 1160 (!) embert fertőzött meg. A szuperterjesztők gyors felismerése és izolálása segíthet a járványfolyamat megszakításában, kiváltképp nozokomiális átvitel esetén [10,23].

\section{A COVID-19 feltételezett patogenezise}

\section{A SARS-CoV-2 receptorhoz kötése és életciklusa}

In vitro és állatkísérletek eredményei alapján a SARSCoV-2 receptora az ACE2, egy olyan transzmembrán fehérje, mely a II. típusú alveoláris epithelsejteken kívül szívizomsejteken, vesetubulus-, gyomor- és bélhámsejteken, urothelsejteken, valamint vascularis endothelsejteken, monocytákon/macrophagokon, és a here több sejtjén is expresszálódik. Az S-proteinnek az ACE2 aktív centrumához való kötődése receptormediálta endocytosist vagy a plazmamebránnal történő fúziót indít be. Bármely folyamat eredményeképp a SARS-CoV-2 a sejtbe transzlokálódik (entry). A receptormediálta endocytosis során a virion a megkötött receptorával együtt endosomába kerül, melyben a cathepsin L aktiválja az S-proteint. A vírus burka fuzionál az endosoma mebránjával, ezzel felszabadítva a virális RNS-t a citoplazma irányába (fusion). Az alternatív út során az S-proteint egy koreceptorként funkcionáló transzmembrán szerin-proteáz, a transmembrane protease serine 2 (TMPRSS2) aktiválja, és a fúzió már a sejtmembránban megtörténik, így a plazmába csak az RNS kerül (priming). Utóbbi folyamat valószínúleg kevésbé aktiválja a gazdaszervezet celluláris immunitását, így hatékonyabban szolgálja a vírus intracelluláris túlélését és replikációját. A szabad RNS-ről virális non-struktúrfehérjék íródnak át, melyek közül két proteáz funkciójú fehérje több alegység hasításával létrehozza a virális RNS-polimerázt (replikáz). A virális RNS-polimeráz ezután elvégzi az egyes struktúrfehérjék, valamint a teljes vírusgenom RNS-ének transzkripcióját is. A templátokról a burokfehérjék transzlációjával az endoplazmatikus retikulum (ER) felszínén létrejön az üres virion, míg a citoplazmában összeáll a vírusgenomból és a hozzá kapcsolódó struktúrfehérjéből álló nukleokapszid. Utóbbi az ER-on keresztül transzportálódik a Golgi-apparátus felé, miközben egyesül a virion prekurzorral (assembly). A kész virion exocytosissal ürül ki a fertőzött sejtből. A COVID-19 antivirális kezelésében felmerülő gyógyszerek a fenti ciklus bizonyos pontjait hívatottak in vitro és in vivo gátolni. Így a rekonvaleszcens vérplazma a belépést, a camostat és nafamostat a TMPRSS2-t, az umifenovir a membránfúziót, a chloroquin/hydroxychloroquin az endo- és exocytosist, a lopinavir/ritonavir fix kombináció és a darunavir a proteázokat, míg a favipiravir, a remdesivir és a ribavirin az RNS-polimerázt blokkolja [10, 24, 25]. 


\section{A SARS-CoV-2 által generált immunválasz}

A SARS-CoV-2 fertőzés következtében létrejövő immunválaszról egyelőre kevés adattal rendelkezünk, az ismeretek egy részét a korábbi magas patogenitású humán coronavírusokkal kapcsolatos tapasztalatokból extrapolálják (1. ábra). A korai fertőzés a felső légutakban jön létre. Egy nemrégiben publikált hipotézis szerint, még az adaptív immunválasz kifejlődése előtt, az első barrierként funkcionáló veleszületett immunitás felelhet a vírus gyors eliminálásért. A veleszületett immunitás celluláris ( $\mathrm{NK}$ [natural killer]- és $\gamma \delta$-T-sejtek stb.), valamint humorális komponensei (komplement- és koagulációs kaszkád, szérum mannózkötő lektin [mannose binding lectin, MBL], szérum anti-glycan természetes IgM- és IgA-, valamint mucosalis IgA-antitestek, interferonok [IFN] stb.) a fertőzött sejtek elpusztítása és az adaptív immunitás beindítás révén, egymással összhangban akadályozzák a további vírusinváziót. Amennyiben a SARS-CoV-2 infektív dózisa magas, és a veleszületett immunitás genetikai vagy szerzett tényezők miatt nem képes kontrollálni a fertőzést, a vírus még az adaptív immunitás kifejlődése előtt továbbjuthat az alsó légutakba [26, 27].

Az alsó légút sejtjeiben történő replikáció során a virális peptidek - kiváltképp az S-protein és a nukleokapszid idegenként kerülnek felismerésre. A fertőzött sejtek ezeket I. típusú MHC-jükön keresztül prezentálják, emellett az epithelsejtek döntően IL-6 (interleukin-6), IL-1 $\beta$,
IFNa/ $\beta$ és IFN $\gamma$ termelésével közvetlenül aktiválják az alveolaris macrophagokat is. A folyamat a celluláris és humorális immunválasz bekapcsolódásához vezet: a CD8+ citotoxikus T-sejtek (Tc) a fertőzött sejtek apoptosisát idézik elő, valamint az interstíciumban aktivált dentritikus sejtekkel (DC) együtt nagy mennyiségü citokint (Tc: IFN $\gamma$, TNFa, DC: IFN $\alpha / \beta$ ) termelnek. A CD4+ helper T-sejtek a CD19+ B-sejtek aktivációján keresztül ugyanakkor antitesttermelődést, és további citokinválaszt (Th: IFN $\gamma$, TNFa, IL-2) indítanak be. A vírus közvetlenül fertőzi a monocyta/macrophag rendszer sejtjeit - így az alveolaris macrophagokat - is, ezzel további citokintermelést eredményezve. A vérkeringésben megjelenő citokinek elsőként a myeloid eredetű immunocytákat aktiválják, melyek a fertőzés kapuját jelentő tüdőben kilépnek az interstíciumba. Az így extravazált neutrofil granulocyták és aktivált macrophagok szöveti gyulladást idéznek elő, és további mediátorokat, döntően TNFa-t és IL-6-ot szekretálnak. A lobsejtes infiltráció fokozódását a szervkárosodás, és a klinikai tünetek súlyosbodása követi [24, 26, 28-33].

A COVID-19 a betegség első napjaitól kezdve abszolút lymphopeniával jár, melynek mértéke a betegség súlyosságával, valamint a szérum IL-2-, IL-6- és TNFa-szintekkel korrelál. Irodalmi adatok alapján valamennyi keringő lymphocytafrakcióban (CD4+ és CD8+ T-sejtek, B-sejtek, NK-sejtek) jelentős depléció látható. A sejtfogyás a fenti szöveti redisztribúcióval, a SARS-CoV-2 direkt lym-

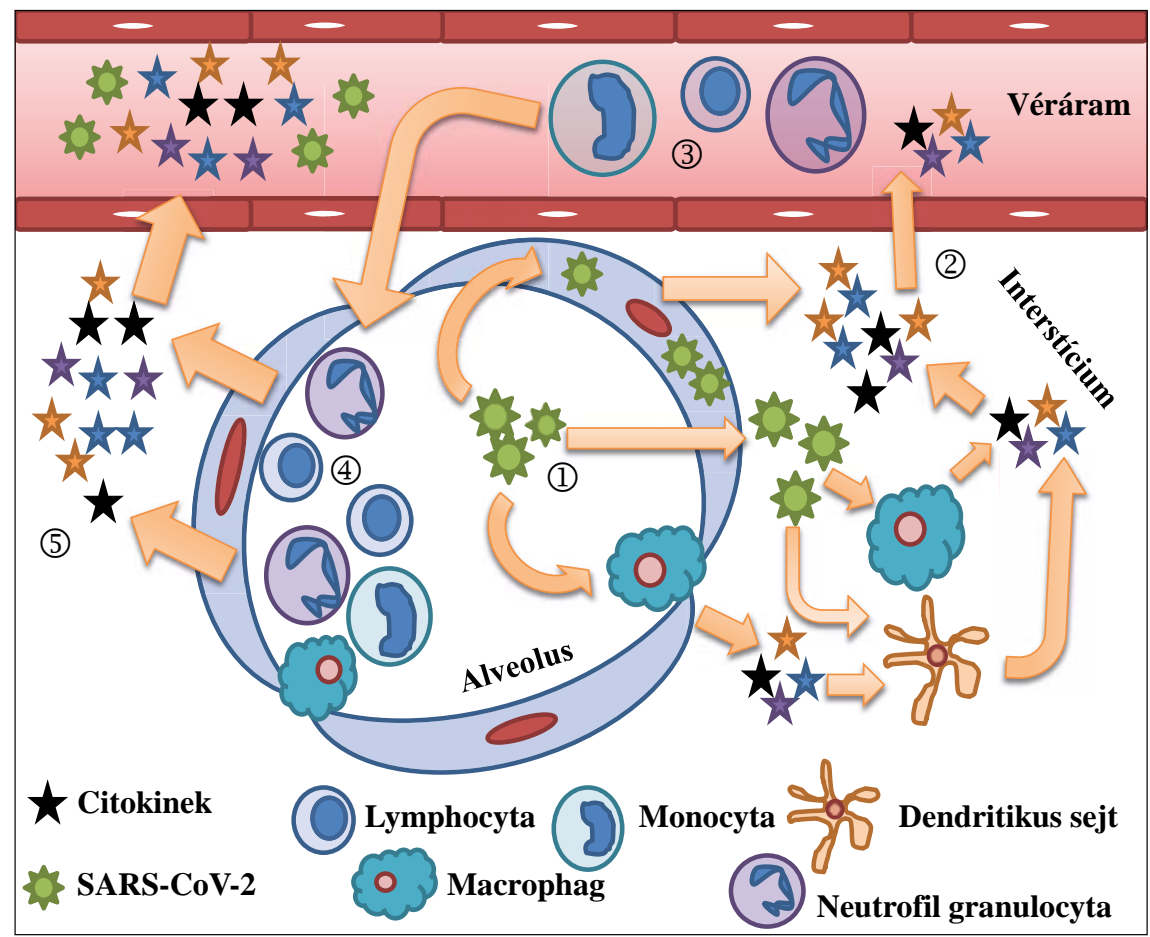

1. ábra. A SARS-CoV-2 pulmonalis fertőzésének immunmechanizmusa és a citokinvihar létrejötte ([24] alapján). 1: a vírus az alveolusba jutva megfertőzi a II. típusú pneumocytákat és az alveolaris macrophagokat, majd kijut az interstíciumba, 2: a vírus megfertőzi a dendritikus sejteket és a szöveti macrophagokat is, citokinek felszabadulását eredményezve, 3: a citokinek a véráramba jutva aktiválják a keringő immunocytákat, 4: a citokinek hatására a monocyták, neutrofil granulocyták és lymphocyták tobzódnak az alveolaris térbe, 5: az alveolusban szövetdestruktív gyulladás alakul ki, és a folyamat önmagát erősítve citokinvihart generál. Az egyes grafikai elemek egymáshoz képest nem méretarányosak 
photrop hajlamával, és a lymphopenia irányába ható gyulladásos citokinmiliővel magyarázható. Bár in vitro vizsgálatok alapján a SARS-CoV-2 nem teljesen ismert mechanizmussal a T-sejteket fertőzi, bennük sikeres replikációra nem képes. Nem kizárt, hogy ez a celluláris szintű abortív fertőzés hozzájárul az extrapulmonalis szervek késői infekciójához is. A Tc- és Th-sejtek ezenfelül immunológiai szempontból ún. kimerült fenotípust mutatnak, vagyis immunológiai stimulálhatóságuk és aktivitásuk diszfunkcionális, citokinprofiljuk is ehhez adaptálódik (exhaustion). Egyes vizsgálatok beszámoltak kritikus állapotú COVID-19-betegekben GM-CSF-et termelő CD4+ T-sejtek arányának patológiás fokozódásáról: ezek a sejtek jelentős IL-6- és IFN $\gamma$-felszabadításra képesek további myeloid sejtek toborzásával, és szepszis esetén megjelenésük rosszabb prognózissal társul. Súlyos COVID-19-ben a celluláris immunválasz túlmüködését és a tüdősérülés progresszióját segíti a regulátor T-sejtek (Treg) arányának csökkenése is. Végül, a T-sejtek fiziológiás aktivációját, és az NK-sejtek antivirális müködését a szöveti TNFa/IL-6-túlsúly gátolni képes [24, 26, 28 33].

A COVID-19-betegek vérképében megfigyelt markáns eltérés lehet az eosinopenia is. Más légúti vírusokkal (influenza, parainfluenza, RSV) kapcsolatos kísérleti megfigyelések alapján az eosinophil granulocyták képesek a légúti mucosalis barrierben több módon is korai, hatékony antivirális immunválaszt kiváltani. A COVID-19ben az eosinophil sejtek poolja egyelőre nem tisztázott mechanizmusok következtében fogy el. Feltételezhető, hogy csontvelői szinten gátlódik az eosinophilek képzése, a periférián pedig, az akut infekció generálta citokinhatás miatt fokozódik apoptózisuk. COVID-19-ben az eosinophilek nem jelennek meg az intraalveolaris lobsejtes infiltrátumban, így direkt antivirális funkciójuk a kórképben kérdéses. Ezt támaszthatja alá az a megfigyelés is, hogy a légúti allergiás betegségek és asthma bronchiale nem növelik a negatív klinikai kimenetel rizikóját SARS-CoV-2-fertőzés esetén. A lymphopeniához hasonlóan, az eosinopenia lassú rendeződése is arányos a klinikai javulás mértékével [34].

Immunkompetens felnőttek szérumában a tünetkezdettől számított 7-8. naptól SARS-CoV2-ellenes IgM, majd a 10-11. naptól IgG megjelenése is várható. A jelenleg forgalomban lévő első immunszerológiai kitek az S-protein és a nukleokapszid elleni humorális immunválaszt képesek detektálni, bár a SARS-CoV-2-re vonatkoztatott specificitásuk egyelőre kérdéses (2. ábra). Az még nem tisztázott, hogy mely rekonvaleszcens betegekben, milyen gyorsasággal és teljességgel épül ki védettség, valamint, hogy az így szerzett immunitás meddig tart. Korábbi, alacsony és más magas patogenitású humán coronavírusokkal szerzett tapasztalatok alapján valószínű, hogy a COVID-19 átvészelése - legalábbis rövid távon - protektív immunitást eredményez. Biztatónak tűnik, hogy egy kínai tanulmány eredménye szerint a vizsgált betegek közel 100\%-ában IgG alapú antivirális szerokonverzió jött létre, a válasz detektálását követő 6 napon belül pedig a titer tetőzését lehetett igazolni. A keringő antitestek neutralizáló szerepére utal, hogy amennyiben Rhesus majmokat kísérleti körülmények között SARS-CoV-2-vel inokuláltak, ezt követően pedig rekonvaleszcens plazmát adagoltak, manifeszt infekció nem alakult ki. A szérum SARS-CoV-2-ellenes IgG-titere arányosnak tünik az átvészelt betegség súlyosságával, és a légúti víruskópiaszám csúcsértékével. A SARS-CoV-1 esetén, immunkompetens felnőttekben, a keringő IgG ellenanyagtiter átlagosan 1-3 év alatt kezdett csökkenni. Korai vizsgálatok tanulsága alapján a SARS-COV-2 esetében ez már a tünetkezdettől számított 8 . héttől bekövetkezhet. A reinfekció elleni hosszú távú védelmet így valószínúleg a perzisztáló memória B- és T-sejtek biztosítják. Erre vonatkozóan részleges eredménnyel szolgált az a vizsgálat, mely bizonyította, hogy a COVID-19-et átvészelt betegek 70, ill. 100\%-ában keringő SARS-CoV-2-specifikus CD8+ és CD4+ T-sejtek voltak jelen. Utóbbiak ex vivo S-protein stimulusra szignifikáns immunválasszal reagáltak [26, 31, 35-38].

A hatékony humorális védelmet viszont két másik tényező negatívan befolyásolja. Egyrészt a SARS-CoV-2 S-proteinjének pontmutációjával létrejövő ún. escape mutáns törzs ellen a korábbi, vad törzs okozta fertőzés alkalmával szerzett humorális immunitás nem jelent hatékony védelmet. Ez egyben a vakcinafejlesztés számára is gátat jelenthet. Másrészt a vírusspecifikus, de nem neutralizáló hatású IgG-k facilitálhatják a vírusnak a monocyta/macrophag rendszer sejtjeibe történő, Fc-dependens internalizációját, mely a gyulladásos válasz robbanásszerü fokozódását eredményezheti. Ezt a folyamatot antitestdependens erősítésnek (antibody dependent enhancement, ADE) nevezzük, és kínai tanulmányokban hipotézis szintjén felvetették a COVID-19 patogenezisében játszott szerepét is. A nagy dózisú intravénás immunglobulin COVID-19-ben történő alkalmazásának egyik elvi magyarázatát az ADE jelenségének kivédése adja [26, $31,38,39]$.

\section{Az extrapulmonalis szervek fertözése és a citokinvihar szindróma létrejötte}

Az enyhe esetektől eltekintve a COVID-19 többszervi betegség (1. táblázat). Az extrapulmonalis szervek infekciója feltehetően egyrészt direkt viraemia kapcsán, másrészt a fertőzött immunocyták migrációjával következik be, ennek pontos mechanizmusa azonban nem tisztázott. Nem teljesen világos az sem, hogy a gazdaszervezet mely genetikai és immunológiai tulajdonságai járulnak hozzá a vírus disszeminációjához. A SARS-CoV-2 által károsított szervekben magas ACE2-expresszió mérhető, érintettségük a betegség más-más szakaszában lép fel. Fontos kiemelni az endothel diffúz fertőződésével és gyulladásával járó endotheliitist, mely az endothelsejtek működészavara révén az alvadási rendszer és a komplementkaszkád patológiás aktivációjához, következményes kisérkárosodáshoz és thromboemboliához, ischae- 


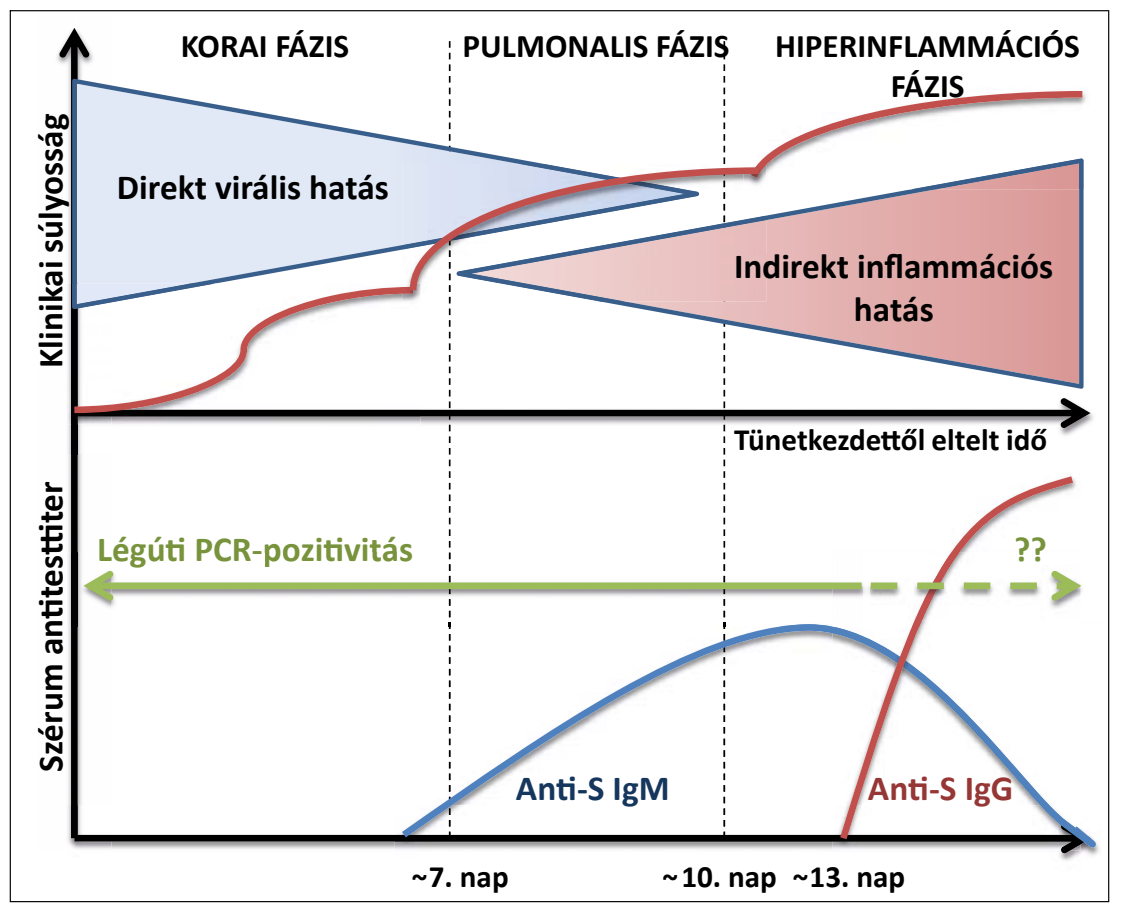

2. ábra. A COVID-19 feltételezett progressziója az immunfunkció függvényében ([60] alapján). A fertőzés korai fázisában az enyhe tünetek dominálnak. A 7. naptól a pulmonális fázisnak megfelelő tünetek és hypoxaemia lép fel. A betegség végstádiumában a citokinvihar okozta többszervi elégtelenség uralja a klinikai képet. A SARS-CoV-2 S-proteinje elleni IgM a 7. nap, míg az IgG a 14. nap körül válik mérhetővé a szérumban ép immunrendszerü felnőtt esetén. A légúti RT-PCRpozitivitás értelemszerúen megelőzi a szerokonverziót, és az IgG-frakció megjelenésével párhuzamosan kezd el lecsengeni, de kellően szenzitív tesztekkel még hetekig pozitív maradhat a klinikai minta. Bővebben ld. a szöveg megfelelő pontjainál

miához vezet, fokozva ezzel a további szervkárosodást. Az endothelitis szerepe mellett szólhat az is, hogy súlyos COVID-19-betegségben az érintetté váló központi és perifériás idegrendszer sejtjei nem expresszálnak ACE2-t, a szervrendszert ellátó vérerek viszont igen [24, 40-44].
A sokszervi károsodás kifejlődését, a fentieken túl, a COVID-19-fertőzés során fellépő az ún. citokinvihar szindróma (cytokine release syndrome, CRS) is elösegíti. A citokinvihar infektív, daganatos vagy autoimmun antigénstimulusra adott excesszív és kontrollálatlan immunválasz. A CRS patomechanizmusával lényegében analógi-

1. táblázat. A SARS-CoV-2 által potenciálisan fertőzött szervek, és klinikai érintettségük leggyakoribb megjelenési formái. Az egyes eltérések a klinikai lefolyás más fázisaiban és súlyossági stádiumaiban fordulnak elő

\begin{tabular}{ll}
\hline Szerv & Klinikai érintettség \\
\hline Központi és perifériás idegrendszer & $\begin{array}{l}\text { Fejfájás, tudatzavar (zavartság, aluszékonyság, delírium), érzékelési zavar (hallucinációk), } \\
\text { aphasia, paresis, görcstevékenység, stroke-nak megfelelö egyéb klinikum } \\
\text { Conjunctivitis, retroorbitális fájdalom, anosmia, dysgeusia }\end{array}$ \\
Szem, orr, nyelv & $\begin{array}{l}\text { Mellkasi fájdalom, myocarditis, ritmuszavar, akut szívelégtelenség tünetei, szívroham, } \\
\text { hirtelen szívhalál }\end{array}$ \\
Vérerek & Endotheliitis, következményes thrombembolia és ischaemia \\
Máj & Hepatomegalia, emelkedett májenzimek, akut májelégtelenség \\
Vese & Akut vesekárosodás és -elégtelenség \\
Belek & Hasi fájdalom, hasmenés, hányinger, hányás \\
Tüdő & Köhögés, tachypnoe, dyspnoe, akut légzési elégtelenség, ARDS \\
Muszkuloszkeletális rendszer & Myalgia, arthralgia, izomgörcsök \\
Bőr & Pernioszerü és bullosus bőrjelenségek az acrákon \\
Vérképzés és véralvadás & Cytopeniák, alvadási zavar, DIC \\
\hline
\end{tabular}

ARDS: akut légzési distressz szindróma, DIC: disszeminált intravaszkuláris koaguláció 
át mutat a haemophagocytás lymphohistiocytosis (HLH), a macrophag aktivációs szindróma (MAS) és a szepszis indukálta szisztémás gyulladásos válaszreakció is (systemic inflammatory response syndrome, SIRS). A CRS-re jellemző tünetek így átfedést mutatnak a súlyos-kritikus állapotú COVID-19-fertőzöttek tünettanával. Belátható, hogy a circulus vitiosusként visszacsatoló immunválasz diszregulált hypercitokinaemia, és a toborzott immunsejtek által mediált szöveti destrukció kialakulásához vezet. A folyamatot közvetítő citokinek közül kiemelkedő szereppel bír a monocytákból, macrophagokból és dentritikus sejtekből felszabaduló proinflammatorikus hatású IL-6, mely kétféleképpen képes a JAK/STAT szignáltranszdukciós kaszkádot aktiválni: az ún. cisz útvonalon keresztül a B- és T-sejtek mellett a neutrofil granulocyták és NK-sejtek, míg a transz útvonalon át elsősorban az endothelsejtek involválódnak. A súlyos COVID-19-betegek mintegy háromnegyedében, míg az enyhe esetek mintegy harmadában észleltek magas szérum IL-6 szintet. Kritikus állapotú betegek körében az IL-6-on túl számos más citokint (TNFa, IL-1 $\beta$, IL-2, IL-6, IL-7, IL-10, IL-12, IL-18, IL-33, GM-CSF) és kemokint (CXCL10/IP-10, CXCL8/IL-8，CCL2/MCP-1， CCL3/MIP-1a，CCL5/ RANTES) is azonosítottak a CRS ko-mediátoraként [33, 44-46].

A citokinvihar patogenezisének ismerete azért is fontos, mert a jelátvitelgátlás potenciális terápiát jelenthet a súlyos és kritikus állapotú COVID-19-betegek számára. A siltuximab IL-6-ellenes, a tocilizumab és sarilumab az IL-6-receptora ellen előállított antitest, míg a downstream jelálvitelt a JAK/STAT inhibítor baricitinib, ruxolitinib és tofacitinib gátolja. Elvi szinten felmerül a IL-1 $\beta$-gátló anakinra, valamint bizonyos TNFa-gátlók alkalmazása (infliximab, adalimumab) is. A világ számos országában zajlanak a biológiai terápiák COVID-19-ben történő hatékony és biztonságos felhasználását tesztelő klinikai vizsgálatok $[10,33,44-46]$.

\section{A COVID-19-ben elhunytak boncolási eredményei}

A funkcionális jellegü eltéréseket, diszregulált immunmechanizmusokat és következményes szervi károsodásokat a boncolásokból származó eddig publikált kórszövettani leletek is alátámasztani látszanak. A COVID-19 első heteiben elhunytak esetében a tüdőben a diffúz alveolaris károsodás (diffuse alveolar damage, DAD) exsudatív formájának megfelelő hyalinmembrant, valamint a II. típusú pneumocyták hyperplasiáját észlelték. A több hétig lélegeztetett betegekben intraalveolaris fibroblastproliferáció is megjelent. A tüdőkapillárisok károsodására a pangás, fibrinoid necrosis, microthrombosis és vérzés, valamint a kialakuló haemosiderosis hívta fel a figyelmet [47, 48]. Az interstíciumban pauci-immunreakció volt leginkább megfigyelhető kevés lymphocyta infiltrációjával. Elektronmikroszópos vizsgálatok az extrapulmonalis szervek - elsősorban a belek és vesék - kapillárisainak endothelsejtjeiben, a fellépő endotheliitis jeleként, a SARS-CoV-2 alkotta inklúziós testek jelenlétét igazolták. Emellett a komplementkaszkád alternatív és lektin úton történő aktiválódása által kiváltott endothelsérülés, és következményes kisérthrombosis is kimutatható volt immunhisztokémiai módszerrel. A májban fokális necrosis mellett lobularis lymphoid infiltráció látszódott, ugyanakkor a szívben jellemző morfológiai elváltozást rendszerint nem lehetett felfedezni [42, 49-51].

\section{A SARS-CoV-2 kimutathatósága rekonvaleszcens betegekböl}

Tünetmentessé váló, vagyis rekonvaleszcens betegek különböző klinikai mintáiban PCR-techinkával még napokig-hetekig igazolható a virális RNS jelenléte. A felső légutakból származó minta az enyhe betegség kezdetétől számított átlagosan 7-14 napig (saját tapasztalat szerint akár 35 napig), súlyos betegséget átvészeltek, valamint kritikus állapotúak körében akár 3-4 hétig is pozitív lehet. Ugyanakkor a székletminták az összes fertőzött mintegy harmadában akár 4-5 hétig is pozitívak maradhatnak. Az ürítés időbeli elhúzódása arányosan nő az életkorral, a víruskópiaszámmal, a lymphopenia és eosinopenia mélységével, valamint az IL-6- és IL-10-szintekkel. Egy vizsgálat során valamennyi utánkövetett beteg légúti PCR eredménye a 6 . hétre negatívvá vált, a medián PCR-pozitivitási idő 24 nap volt. A rekonvaleszcens esetek döntő hányadában a vírus fertőzőképességét in vitro tenyésztés során nem lehetett igazolni, vagyis a PCR-rel elhúzódó ürítést mutató, gyógyult személyek tényleges fertőzőképessége mellett nem szól egyértelmü bizonyíték [10, 52-58].

A korábban dokumentáltan PCR-negatív, rekonvaleszcens személyekben ismét felbukkanó PCR-pozitivitás jelentős figyelmet kapott médiában. A jelenlegi megfogalmazható tudományos konszenzus szerint ezidáig nem dokumentáltak sem humán SARS-CoV-2 reinfekciót, sem pedig tünetmentes, krónikus vírushordozást. Ezek bekövetkezének valószínüsége a SARS-CoV-1-gyel és MERS-CoV-val gyüjtött tapasztalatok alapján csekély. Az ismételt PCR-pozitivitás jelenségének magyarázata feltehetően az, hogy a sorozat-mintavétel kritikus pontjain hiba történik (pl. rossz eszközzel, nem megfelelő anatómiai lokalizációból és módon gyüjtött minta stb.), így a PCR-eredmény - az egyébként még RNS-ürítő embernél - tévesen negatív lesz [10, 52-58].

\section{A COVID-19 klinikai infektológiája}

\section{A COVID-19 típusos tünettana}

A COVID-19-fertőzéstől számított medián lappangási ideje 4-6 nap, maximuma pedig átlagosan 14 nap. A fertőzés leggyakoribb tünete a láz (85-99\%), mely lázcsillapítók szedésével elfedhető. A légúti tünettan vezetői a 
szárazköhögés (60-80\%), és a dyspnoe (30-40\%). A légúti váladék $20-30 \%$-ban purulens is lehet. A tüdők felett krepitációt hallhatunk, ennek hiánya azonban a diagnózist nem zárja ki, megléte pedig nem erősíti azt meg. A betegség legkorábbi tünete lehet a kifejezett fáradtság (45-70\%), az íz- és szagérzés zavara (15-30\%), a fejfájás (15-30\%) és myalgia (10-35\%). A hasmenés (5\%), orrfolyás (5\%) és a torokfájdalom (10\%) nem gyakori tünet, megjelenésük szintén a láz és légúti tünetek előtt várható. Viszonylag új megfigyelés, hogy a betegek 20-30\%-ában acralis, leginkább pernioszerű ill. bullosus bőrjelenségek, 5-10\%-ban pedig kétoldali conjunctivitis lép fel. A betegség progressziójával egyre súlyosabb tünetek jelennek meg, vagy a korábbi tünetek romlanak [10, 59].

\section{A COVID-19 súlyossági stádiumai és időbeli lefolyása}

$\mathrm{Az}$ eddigi irodalmi adatok alapján a SARS-CoV-2 fertőzések mintegy $80 \%$-a enyhe, $15 \%$-a középsúlyos-súlyos, míg 5\%-ban kritikus lefolyású lesz. A betegek egy része tüneteiket szubjektíve alábecsülve - csupán a fertőzés késői fázisaiban jelentkezik a kórházban $[1,6,10,33,60$ 62].

A COVID-19 progresszióját a korábban ismertetett immunmechanizmusokkal összefüggésben a 2 a ábra szemlélteti. A fertőzés korai fázisában az enyhe tünetek (láz, köhögés, hasmenés, fejfájás, arthralgia/myalgia, fáradékonyság stb.) dominálnak. A betegek döntő hányada további progresszió híján nem kerül súlyosabb stádiumba, a virális replikáció és az általa iniciált vírusellenes immunválasz viszonylag regulált marad. Az első tünetek jelentkezésétől a súlyos betegségig eltelt átlagos idő 6-7 nap, a következményes hospitalizációig pedig 7-8 nap telik el. A betegek kisebb részében a több napig tartó stabilitás után hirtelen alakulnak ki a súlyos tünetek - ezt a jelenséget korábban a SARS kapcsán már dokumentálták [1, 6, 10, 33, 60-62].

A 6-7. nap körül a pulmonális fázisnak megfelelő tünetek jelentkeznek: újkeletű vagy súlyosbodó légszomj köhögéssel, mellkasi fájdalommal és romló hypoxaemiával. Ebben a fázisban a leggyakoribb klinikai megjelenési forma a pneumonia. A hospitalizált betegek általában már középsúlyos-súlyos COVID-19-betegségben szenvednek, és bár a felvételt követő órákban-napokban viszonylag stabilnak tünhetnek, klinikai állapotuk gyorsan (akár pár óra alatt is) romolhat. Főleg fiatalabb férfiak körében megfigyelték a markáns panaszok vagy klinikai jelek nélküli súlyos oxigénhiányos állapotot (silent hypoxaemia) [1, 6, $10,33,60-62]$.

A 9-11. nap körül kezdődő hiperinflammációs fázisban a citokinvihar okozta perzisztáló láz és többszervi elégtelenség, valamint az akut légzési distressz-szindróma (acute respiratory distress syndrome, ARDS) vezetheti a klinikai képet. Az intubációig átlagosan 10 nap telik el, az összes COVID-19-beteg 10-15\%-a igényel gépi lélegeztetést. Az intenzív osztályra kerülő betegek között 10- 15\%-ban szekunder bakterális vagy gombainfekció lép fel, mely fokozza a klinikai kép komplexitását (ld. később). Az ARDS kialakulásának valószínúleg legfontosabb rizikófaktorai az életkor és a kísérő betegségek, de érdemes megjegyeznünk, hogy az elérhető irodalmi adatok alapján a gépi lélegeztetésre kerülők közel harmada fiatalabb, komorbiditás nélküli beteg. Az extubációra átlagosan a gépi lélegeztetés megkezdését követő 14-17. napon kerülhet csak sor [1, 6, 10, 33, 60-62].

A betegségkezdettől a halálig átlagosan 2-8 hét telik el. A gépi lélegeztetést igénylő betegek körében a halálozási arány 40-70\% között mozog. Az enyhe COVID-19-betegség teljes gyógyulásához átlagosan 2-3 hét szükséges, súlyos és kritikus állapotú betegeknél ez 4-7 hétig elhúzódhat. A súlyos és kritikus COVID-19-ből felépült betegek ismeretlen arányú részénél maradványbetegségként restriktív tüdőzavar, krónikus szív- és veseelégtelenség maradhat vissza $[1,6,10,33,60-64]$.

\section{A COVID-19-fertözéses szövődményei}

A COVID-19 szövődményeit infektív és noninfektív típusokra oszthatjuk. Irodalmi adatok alapján a betegek 6-21\%-ában a SARS-CoV-2 mellett más vírusok is jelen lehetnek: rhinovírusok, enterovírusok, RSV (respiratory syncytial virus), influenza A/B, HMPV (human metapneumovirus) és adenovírusok [65]. Súlyos és kritikus COVID-19-ben, a felsorolt vírusok légúti mintából, PCR-rel történő identifikálása elősegítheti az adekvát antivirális kezelési stratégiát. Egyes vírusok ellen specifikus gyógyszerrel rendelkezünk, az immunszuppresszív szerek dózisát átmenetileg csökkenthetjük, valamint magas rizikójú betegeknek intravénás immunglobulint adhatunk. Mivel Európában a SARS-CoV-2 járvány első hetei egybeestek a 2019/2020. szezon influenzajárványával, a saját és más centrumok gyakorlatában a pneumoniás betegek az influenza etiológiai szerepének kizárásáig empirikus oseltamivir terápiában is részesültek [10].

Másodlagos bakteriális infekciók kialakulása tekintetében a kritikus állapotú, intenzív osztályon kezelt betegek esetében legnagyobb a kockázat. Körükben e szövődmények 4-22\%-ban fordulnak elő. Leggyakrabban egészségügyi ellátással (healthcare-acquired pneumonia, HAP), ill. gépi lélegeztetéssel összefüggő tüdőgyulladás (ventilator-associated pneumonia, VAP), valamint kanülasszociált véráraminfekció lép fel. Az intenzív osztályos felvételtől a szekunder infekció(k)ig medián 10-12 nap telik el. A bakteriális patogének spektruma valószínúleg az adott centrum nozokomiális flóráját reprezentálja (Staphylococcus aureus, Streptococcus pneumoniae, Legionella pneumophila, Klebsiella pneumoniae, Escherichia coli, Enterobacter cloacae, Acinetobacter baumannii, Pseudomonas aeruginosa, Serratia marcescens stb.). A diagnosztika alapját hemokultúrák, és a mélylégúti minták (bronchoalveolaris lavage [BAL], mini-BAL) képezik. Az invazív bakteriális fertőzések - így a véráraminfekciók - kliniku- 
ma nem specifikus: visszatérő, újkeletű, vagy perzisztáló láz vagy hypothermia, hemodinamiai instabilitás, a légzési (lélegeztetési) paraméterek rosszabbodása, tudatzavar stb. mind jelezhetik bakteriális szepszis kezdetét [66-68]. Mivel a citokinvihar klinikailag elkülöníthetetlen az infekciók következtében fellépő szepszistől, széles spektrumú antibiotikumok használata ezen betegek körében rendszerint elkerülhetetlen: $80-100 \%$-uk részesül ily módon empirikus vagy célzott terápiában. A COVID-19ben a helyes antibiotikum-használat (antimicrobial stewardship) komplex kérdés, a döntéseket egyénről egyénre érdemes mérlegelni, infektológus szakorvos bevonásával. Ezek a megfontolások központi szerepet fognak játszani a szükségtelen terápiák korlátozásában, és a következményes szelekciós nyomás csökkentésében [69].

Viszonylag újkeletű megfigyelés, hogy egyes súlyos víruspneumonitisek miatt lélegeztetett, kritikus állapotú felnőttek esetében az intubációt követő átlag 6-8. naptól kezdve akut invazív tüdőaspergillosis (invasive pulmonary aspergillosis, IPA) léphet fel. Fontos tudnunk, hogy szemben a malignus hematológiai betegek körében „megszokott”, súlyos fokú immunszuppressziót jelző ún. klasszikus rizikótényezőkkel (allogén csontvelőtranszplantáció, akut graft-versus-host betegség, akut myeloid leukaemia indukciós/reindukciós kezelése, tartós-mély neutropenia, elhúzódó szisztémás kortikoszteroidhasználat, celluláris immunitást gátló más gyógyszerek stb.), ezek a betegek felvételkor vagy nem rendelkeznek kimutatható rizikófaktorokkal, vagy kockázati tényezőik a hematológiai betegekéhez képest kisebb fokú immunszuppresszióra (pl. kezelt autoimmun kórkép), esetleg tüdőkárosodásra (pl. krónikus obstruktív tüdőbetegség, COPD) utalnak. Az IPA megnövekedett rizikóját a súlyos-komplikált influenza kapcsán írták le először, de úgy tünik, a SARSCoV-2 okozta súlyos alsó légúti infekció kapcsán is kialakulhat, különösképpen ARDS jelenlétében. Az eddigi adatok alapján a lélegeztetettek $19-20 \%$-át is érintheti IPA, így a korai - még nem szisztematikusan gyüjtött kínai adatok szerint 8-15\%-uk esetében antifungális terápia alkalmazása is szükségessé vált. Az IPA felismerését a rizikófaktorok felmérésén túl a mellkasi CT ilyen diagnosztikus irányra (is) gyanús progressziója, a szabályosan vett mélylégúti mintából tenyésztéssel és kenetvizsgálattal igazolható fonalasgomba jelenléte, valamint a mélylégúti mintából és a szérumból paralel mért, Aspergillus $s p$.-re specifikus gombamarker, a galaktomannán, mérése támogathatja $[70,71]$.

Candidaemia a többszörös kockázati tényezők megléte következtében kritikus állapotú COVID-19-betegekben is előfordulhat, de a véráramfertőzés pontos incidenciája nem ismert. Egy olasz közlemény szerint a tocilizumabbal kezelt betegek 5,9\%-ánál lépett fel 14 napon belül candidaemia, de a gyógyszerrel való ok-okozati összefüggés nem egyértelmü [72]. Felismerését a rizikófaktorok aktív keresése mellett a hemokultúrák gombatenyésztése, valamint a szérumból végzett panfungális gombamarker, a béta-D-glukán mérése segítheti. $P$. jirovecii pneumonia SARS-CoV-2-koinfekcióként való előfordulási gyakoriságáról nincs adat.

\section{A COVID-19 non-infektív szövödményei}

A COVID-19 patomechanizmusának ismeretében nem meglepő, hogy a pulmonalis fázis legfőbb szövődménye az ARDS, valamint a következményes hypoxaemia és cardialis terhelés (1. táblázat). ARDS az összes beteg kb. 2040\%-ában alakul ki a fertőzést követő medián 8-9. napon, és jellemzően a gépi lélegeztetés abszolút indikációját képezi. A szív közvetlen érintettsége 9-17\%-ban szívinfarktust, myocarditist, malignus ritmuszavarokat eredményezhet. A vesekárosodás $10-20 \%$-ban akut veseelégtelenségig progrediálhat. Az idegrendszert ellátó erek gyulladása változatos neurológiai tünettanhoz vezethet. A citokinvihar fázisában perzisztáló láz mellett pancytopenia és sokszervi elégtelenség uralja a klinikumot [10, 73, 74].

A COVID-19 utóbb felismert, fontos sajátossága az alvadási rendszer kóros aktiválódása, mely klinikailag artériás és vénás thrombemboliára hajlamosít. A coagulopathia mértéke arányos a betegség súlyosságával, így a patomechanizmus alapját valószínüleg az excesszív gyulladás, thrombocytaaktiváció és endotheldiszfunkció adja. A vénás thrombembolia, beleértve a kiterjedt mélyvénás thrombosist és a tüdőemboliát, az intenzív terápiában részesülő betegek $20-45 \%$-át is érintheti, még akkor is, ha profilaktikusan véralvadásgátló terápiában részesülnek. Utóbbi jelenség miatt a véralvadásgátlás aktivitását szükséges lehet a lehetséges maximumig fokozni. Az igazolt coagulopathiában szenvedő, súlyos vagy kritikus COVID-19-betegek körében mind a nem frakcionált, mind feltehetűen az alacsony mólsúlyú heparinkezelés valószínúleg javítja a prognózist. Az artériás thrombosisok incidenciájáról biztos számadatok egyelőre nem állnak rendelkezésre. A folyamat elsősorban a coronariákat, az agyi és végtagi nagyereket érinti, disztális akut ischaemiához és szövetelhaláshoz vezetve. Érelzáródás létrejöhet a klasszikus kardiometabolikus rizikófaktorok jelenléte nélkül is, pl. fiatal, egyébként egészséges emberekben is. A vérzés ritka jelenség, de antikoaguláns kezelés szövődményeképp felléphet [51, 75-78].

\section{A COVID-19 klinikuma immunszupprimált betegekben}

Az elérhető adatok alapján az onkológiai és malignus hematológiai betegségekben szenvedő emberekben a SARS-CoV-2 fertőzési rátája nem magasabb a populáció egészséges tagjaihoz viszonyítva [79].

A malignus hematológiai alapbetegségekben szenvedő, emiatt súlyosan immunszupprimáltnak tekintendő SARSCoV-2 fertőzöttek betegséglefolyásáról és klinikai kimeneteléről egyelőre kevés információ áll rendelkezésünkre. Az egyik korai kínai tanulmány szerint a COVID-19 
súlyosabb lefolyást mutatott a fenti csoportban: 38\%-ban volt szükség intenzív osztályos felvételre, és az összes eset 62\%-a végződött halállal. A COVID-19 diagnózisa a legutolsó ciklus immun-kemoterápia utolsó napjától számítva a medián 9. napon született meg. A láz-dyspnoe-köhögés triásza hematológiai betegekben is jellegzetes volt. A vizsgált kohorsz betegeinek 59\%-át akut leukaemiában szenvedők alkották, a fertőzés kezdetekor 46\%-uk nem volt komplett remisszióban [80]. Alacsony betegszámú esetsorozat-vizsgálatok alapján krónikus lymphoid leukaemiások körében a Bruton-tirozinkináz-inhibítor (BTK) szedése nem járt súlyos klinikai kimenetellel, míg krónikus myeloid leukaemiások körében a TK-terápia nem fokozta szignifikánsan a fertőzés rizikóját az egyébként egészségesekhez viszonyítva [81, 82]. Ezen tapasztalatokkal szemben brit myeloma multiplexben (MM) szenvedő betegek eseteit áttekintve a kórházi mortalitás kifejezetten magas, $54.6 \%$ volt, melyre az előrehaladott életkor, férfi prevalencia és relabált-refrakter stádiumú $\mathrm{MM}$ rizikót jelentett [83].

Az onkológiai betegek körében hasonló tendenciát figyeltek meg kínai kohorszadatok feldolgozása kapcsán: az aktív malignitás független tényezőként mintegy 3.5szörösére emelte a negatív klinikai kimenetel (intenzív osztályos felvétel vagy halál) valószínüségét felnőtt betegek körében [84]. Egy friss tanulmány eredményei alapján az aktív daganatos betegség növeli meg a legkifejezettebben az intenzív osztályos felvétel vagy a kórházi halálozás kockázatát. Egy metaanalízis tanulsága szerint pedig a szolidszerv-malignitás súlyos lefolyású COVID-19-re hajlamosít $[85,86]$. A szolidszerv-transzplantáltak körében - az aktív malignitásban szenvedő betegekhez hasonlóan - SARS-CoV-2 fertőzés esetén súlyosabb klinikai lefolyásra kell számítani. Az eddigi legnagyobb esetszámot magába foglaló elemzés eredményei alapján körükben a láz a vártnál ritkább (70\%), a köhögés és a dyspnoe hasonló gyakoriságú tünet volt. A kórházi halálozás $24 \%$, légzési elégtelenség miatti intenzív osztályos felvétel $35 \%$ volt [87].

\section{Összefoglalás}

„Tudom, melyik fa mit teremhet; Tudom, melyik mily nedvet enged. Tudom, minden mögött van ok.”

François Villon

Mindezek alapján láthatjuk, hogy a SARS-CoV-2 zoonotikus eredetû, magas patogenitású vírus, mely a közelmúltban evolúciós szempontból sikeresen végrehajtotta a fajok közötti ugrást. Molekuláris virulenciafaktoraival adaptálódott a humán transzmisszió fenntartására, és a fertőzött sejt fiziológiás müködéseinek saját megújítása érdekében történő eltérítésére. A COVID-19 bár légúti kiindulású, ám az enyhe esetektől eltekintve mégis sok- szervi betegség. A feltételezett patomechanizmusa alapján nem csupán a SARS-CoV-2 direkt virális hatása, hanem az általa generált kóros celluláris és humorális immunválasz, a vérben keringő proteázkaszkádok aktiválódása, valamint a citokinvihar is hozzájárul a jelentős morbiditáshoz és mortalitáshoz. A feltételezett patomechanizmus helyességét boncolási leletek is erősíteni látszanak. A korai, gyors diagnosztika elengedtetetlen. Ennek alapját a típusos klinikum felmérése képezi a betegség időbeli lefolyásának függvényében. A csökkent immunitású betegek körében a tünettan valószínüleg nem tér el az immunkompetens betegekétől, azonban súlyosabb lefolyásra és klinikai kimenetelekre lehet számítani.

Nyilatkozat: A közlemény más folyóiratban korábban nem jelent meg, és máshová beküldésre nem került. A levelező szerző elolvasta a szerzői útmutatót.

Érdekeltségek: A szerzőknek a cikk megírásával és megjelenésével kapcsolatban nincsenek érdekeltségeik.

Anyagi támogatás: SZBG az EFOP-3.6.3-VEKOP-16-201700009 „Kiegészítő Kutatási Kiválósági Ösztöndíj”-ban és az Innovációs és Technológiai Minisztérium ÚNKP-19-3I-SE-74 kódszámú „Új Nemzeti Kiválóság Programjá”-nak szakmai támogatásában részesült. A közlemény megírása, illetve a kapcsolódó irodalmi kutatómunka közvetlen anyagi támogatásban nem részesült.

Szerzői munkamegosztás: Sz.B.G. - irodalomkutatás, a kézirat szövegezése, B.I., R.M., G.L., L.B., M.D., B.G., P.M., M.G., K.Z., Sz.J. és R.P. - a kézirat szövegezése, S.J. - a kézirat szövegezése, elkészültének szakmai felügyelete, V-N.I. - a kézirat szövegezése, a coronacentrum és a tudományos konzorcium vezetése.

A levelező szerző tisztelettel kéri a Szerkesztőséget és a Kiadót, hogy a téma prioritása, és a levelező szerző affiliációja alapján a közleményt online is elérhető Open Access formátumban szíveskedjenek megjelentetni publikációra való elfogadás esetén.

\section{Irodalom}

[1] Szabó B. In the middle of a new pandemic - what we know about COVID-19. [Egy új világjárvány közepén - amit eddig a COVID-19-ről tudni vélünk.] Orvostovábbképző Szemle 2020. [Hungarian]

[2] Zhou P, Yang XL, Wang XG, et al. A pneumonia outbreak associated with a new coronavirus of probable bat origin. Nature 2020; 579(7798): 270-273.

[3] Tang X, Wu C, Li X, et al. On the origin and continuing evolution of SARS-CoV-2. Nat Sci Rev. 2020. [epub, accessed: May 25, 2020]

[4] Ceraolo C, Giorgi FM. Genomic variance of the 2019-nCoV coronavirus. J Med Virol. 2020; 92(5): 522-528.

[5] WHO. Novel Coronavirus (2019-nCoV) Situation Report - 12. 2020.

[6] WHO. Report of the WHO-China Joint Mission on Coronavirus Disease 2019 (COVID-19). 2020 
[7] Kemenesi G, Zeghbib S, Somogyi BA, et al. Multiple SARSCoV-2 introductions shaped the early outbreak in Central Eastern Europe: comparing Hungarian data to a worldwide sequence data-matrix. medRxiv 2020. [epub, accessed: May 25, 2020]

[8] Andersen KG, Rambaut A, Lipkin WI, Holmes EC, Garry RF. The proximal origin of SARS-CoV-2. Nat Med. 2020; 26(4): 450452.

[9] Shi J, Wen Z, Zhong G, et al. Susceptibility of ferrets, cats, dogs, and other domesticated animals to SARS-coronavirus 2 . Science 2020. [epub, accessed: May 25, 2020]

[10] Cevik M, Bamford CGG, Ho A. COVID-19 pandemic-a focused review for clinicians. Clin Microbiol Infect. 2020. [epub, accessed: May 25, 2020]

[11] CDC. How COVID-19 Spreads. Available from: https://www. cdc.gov/coronavirus/2019-ncov/prevent-getting-sick/how-covid-spreads.html [accessed: May 25, 2020]

[12] van Doremalen N, Bushmaker T, Morris D, et al. Aerosol and surface stability of SARS-CoV-2 as compared with SARS-CoV-1. NEJM 2020. [epub, accessed: May 25, 2020]

[13] Hui KPY, Cheung M-C, Perera RAPM, et al. Tropism, replication competence, and innate immune responses of the coronavirus SARS-CoV-2 in human respiratory tract and conjunctiva: an analysis in ex-vivo and in-vitro cultures. Lancet Resp Med. 2020 [epub, accessed: May 25, 2020]

[14] Groß R, Conzelmann C, Müller JA, et al. Detection of SARS CoV-2 in human breastmilk. Lancet 2020. [epub, accessed: May $25,2020]$

[15] Meselson M. Droplets and aerosols in the transmission of SARS CoV-2. NEJM 2020. [epub, accessed: May 25, 2020]

[16] Anfinrud P, Stadnytskyi V, Bax C, Bax A. Visualizing speech-generated oral fluid droplets with laser light scattering. NEJM 2020. [epub, accessed: May 25, 2020]

[17] NEJM JWatch. SARS-CoV-2 may be transmissible by normal breathing. Available from: https://www.jwatch.org/fw116519/ 2020/04/05/sars-cov-2-may-be-transmissible-normal-breathingcloth [accessed: May 25, 2020]

[18] He X, Lau EHY, Wu P, et al. Temporal dynamics in viral shedding and transmissibility of COVID-19. Nat Med. 2020; 26(5): 672675.

[19] Li R, Pei S, Chen B, et al. Substantial undocumented infection facilitates the rapid dissemination of novel coronavirus (SARSCoV2). Science 2020. [epub, accessed: May 25, 2020]

[20] CDC. Asymptomatic and Presymptomatic SARS-CoV-2 Infections in Residents of a Long-Term Care Skilled Nursing Facility - King County, Washington, March 2020. MMRW 2020; 69(13): 377-381.

[21] CDC. Presymptomatic Transmission of SARS-CoV-2 - Singapore, January 23-March 16, 2020. MMRW 2020; 69(14): 411-415.

[22] Riou J, Althaus CL. Pattern of early human-to-human transmission of Wuhan 2019 novel coronavirus (2019-nCoV), December 2019 to January 2020. Euro Surveill. 2020; 25(4): 1-10.

[23] Reuters. How coronavirus cases exploded in South Korean churches and hospitals. Available from: https://graphics.reuters. com/CHINA-HEALTH-SOUTHKOREA-CLUSTERS / 0100B5G33SB/index.html [accessed: May 25, 2020]

[24] Zhou G, Chen S, Chen Z. Advances in COVID-19: the virus, the pathogenesis, and evidence-based control and therapeutic strategies. Front Med. 2020; 14(2): 117-125.

[25] Pampel J. SARS-CoV-2 Life Cycle: Stages and Inhibition Targets. Available from: https://www.antibodies-online.com/resources/ 18/5410/sars-cov-2-life-cycle-stages-and-inhibition-targets/ [accessed: May 25, 2020]

[26] Vabret N, Britton GJ, Gruber C, et al. Immunology of COVID-19: current state of the science. Immunity 2020.

[27] Matricardi PM, Dal Negro RW, Nisini R. The first, holistic immunological model of COVID-19: implications for prevention, diagnosis, and public health measures. Pediatr Allergy Immunol. 2020. [epub, accessed: May 25, 2020]
[28] Wang X, Xu W, Hu G, et al. SARS-CoV-2 infects T lymphocytes through its spike protein-mediated membrane fusion. Cell Mol Immunol. 2020. [epub, accessed: May 25, 2020]

[29] Xu X, Gao X. Immunological responses against SARS-coronavirus infection in humans. Cell Mol Immunol. 2004; (2): 119-122.

[30] Liu Z, Long W, Tu M, et al. Lymphocyte subset (CD4+, CD8+) counts reflect the severity of infection and predict the clinical outcomes in patients with COVID-19. J Infect. 2020. [epub, accessed: May 25, 2020]

[31] Xiao AT, Gao C, Zhang S. Profile of specific antibodies to SARSCoV-2: The first report. J Infect. 2020. [epub, accessed: May 25, 2020]

[32] Wan S, Yi Q, Fan S, et al. Relationships among lymphocyte subsets, cytokines, and the pulmonary inflammation index in coronavirus (COVID-19) infected patients. Br J Haematol. 2020; 189(3): 428-437.

[33] Szekanecz Z, Rákóczi É, Bálint P, et al. Immunological and rheumatologic aspects of COVID-19. [A COVID-19 immunológiai és reumatológiai vonatkozásai.] Immunol Szemle 2020. [epub, accessed: May 25, 2020] [Hungarian]

[34] Lindsley AW, Schwartz JT, Rothenberg ME. Eosinophil responses during COVID-19 infections and coronavirus vaccination. J Allergy Clin Immunol. 2020. [epub, accessed: May 25, 2020]

[35] Long QX, Liu BZ, Deng HJ, et al. Antibody responses to SARSCoV-2 in patients with COVID-19. Nat Med. 2020. [epub, accessed: May 25, 2020]

[36] Grifoni A, Weiskopf D, Ramirez SI, et al. Targets of T cell responses to SARS-CoV-2 coronavirus in humans with COVID-19 disease and unexposed individuals. Cell 2020. [epub, accessed: May 25, 2020]

[37] To KK-W, Tsang OT-Y, Leung W-S, et al. Temporal profiles of viral load in posterior oropharyngeal saliva samples and serum antibody responses during infection by SARS-CoV-2: an observational cohort study. Lancet Inf Dis. 2020; 20(5): 565-574.

[38] Bao L, Deng W, Gao H, et al. Lack of reinfection in Rhesus macaques infected with SARS-CoV-2. bioRxiv 2020. [epub, accessed: May 25, 2020]

[39] Korber B, Fischer WM, Gnanakaran S, et al. Spike mutation pipeline reveals the emergence of a more transmissible form of SARSCoV-2. bioRxiv 2020. [epub, accessed: May 25, 2020]

[40] Bennett CE, Anavekar NS, Gulati R, et al. ST-segment elevation, myocardial injury, and suspected or confirmed COVID-19 patients: Diagnostic and treatment uncertainties. Mayo Clin Proc. 2020. [epub, accessed: May 25, 2020]

[41] Escher R, Breakey N, Lammle B. Severe COVID-19 infection associated with endothelial activation. Thromb Res. 2020; 190: 62.

[42] Magro C, Mulvey JJ, Berlin D, et al. Complement associated microvascular injury and thrombosis in the pathogenesis of severe COVID-19 infection: a report of five cases. Transl Res. 2020. [epub, accessed: May 25, 2020]

[43] Zhou B, She J, Wang Y, et al. The clinical characteristics of myocardial injury in severe and very severe patients with 2019 novel coronavirus disease. J Infect. 2020. [epub, accessed: May 25, 2020]

[44] Li H, Liu L, Zhang D, et al. SARS-CoV-2 and viral sepsis: observations and hypotheses. The Lancet 2020; 395(10235): 15171520.

[45] Merad M, Martin JC. Pathological inflammation in patients with COVID-19: a key role for monocytes and macrophages. Nat Rev Immunol. 2020. [epub, accessed: May 25, 2020]

[46] Moore J, June C. Cytokine release syndrome in severe COVID-19. Science 2020.

[47] Tian S, Xiong Y, Liu H, et al. Pathological study of the 2019 novel coronavirus disease (COVID-19) through postmortem core biopsies. Mod Pathol. 2020. [epub, accessed: May 25, 2020]

[48] Barton LM, Duval EJ, Stroberg E, et al. COVID-19 autopsies, Oklahoma, USA. Am J Clin Pathol. 2020; 153(6): 725-733. 
[49] Menter T, Haslbauer JD, Nienhold R, et al. Post-mortem examination of COVID19 patients reveals diffuse alveolar damage with severe capillary congestion and variegated findings of lungs and other organs suggesting vascular dysfunction. Histopathology 2020. [epub, accessed: May 25, 2020]

[50] Varga Z, Flammer AJ, Steiger P, et al. Endothelial cell infection and endotheliitis in COVID-19. The Lancet 2020; 395(10234): 1417-1418.

[51] Fox SE, Akmatbekov A, Harbert JL, et al. Pulmonary and cardiac pathology in Covid-19: The first autopsy series from New Orleans. medRxiv 2020. [epub, accessed: May 25, 2020]

[52] Xiao AT, Tong YX, Zhang S. Profile of RT-PCR for SARS-CoV-2: a preliminary study from 56 COVID-19 patients. Clin Infect Dis. 2020. [epub, accessed: May 25, 2020]

[53] Fang Z, Zhang Y, Hang C, et al. Comparisons of viral shedding time of SARS-CoV-2 of different samples in ICU and non-ICU patients. J Infect. 2020. [epub, accessed: May 25, 2020]

[54] Zhou B, She J, Wang Y, et al. The duration of viral shedding of discharged patients with severe COVID-19. Clin Infect Dis. 2020 [epub, accessed: May 25, 2020]

[55] Jiang M, Li Y, Han M, et al. Recurrent PCR positivity after hospital discharge of people with coronavirus disease 2019 (COVID-19). J Infect. 2020. [epub, accessed: May 25, 2020]

[56] Lin A, He Z, Zhang S, et al. Early risk factors for the duration of SARS-CoV-2 viral positivity in COVID-19 patients. Clin Infect Dis. 2020. [epub, accessed: May 25, 2020]

[57] Du X, Yu X, Li Q, et al. Duration for carrying SARS-CoV-2 in COVID-19 patients. J Infect. 2020. [epub, accessed: May 25, 2020]

[58] Zhou X, Li Y, Li T, et al. Follow-up of asymptomatic patients with SARS-CoV-2 infection. Clin Microbiol Infect. 2020. [epub, accessed: May 25, 2020]

[59] Yetmar ZA, Issa M, Munawar S, et al. Inpatient care of patients with COVID-19: A guide for hospitalists. Am J Med. 2020. [epub, accessed: May 25, 2020]

[60] Siddiqi HK, Mehra MR. COVID-19 illness in native and immunosuppressed states: A clinical-therapeutic staging proposal. J Heart Lung Transplant. 2020; 39(5): 405-407.

[61] Guan WJ, Ni ZY, Hu Y, et al. Clinical characteristics of coronavirus disease 2019 in China. N Engl J Med. 2020; 382(18): 1708-1720.

[62] Wu Z, McGoogan J. Characteristics of and important lessons from the coronavirus disease 2019 (COVID-19) outbreak in China JAMA 2020. [epub, accessed: May 25, 2020]

[63] Korsos A, Kupcsulik S, Lovas A, et al. Diagnostic consideration and bedside estimation of the prognosis in COVID-19 patients. [Diagnosztikus lépések és a betegség prognózisának becslése COVID-19-fertőzött betegeken] Orv Hetil. 2020; 161(17): 667671. [epub, accessed: May 25, 2020] [Hungarian]

[64] Auld S, Caridi-Scheible M, Blum JM, et al. ICU and ventilator mortality among critically ill adults with COVID-19. medRxiv 2020. [epub, accessed: May 25, 2020]

[65] Kim D, Quinn J, Pinsky B, et al. Rates of co-infection between SARS-CoV-2 and other respiratory pathogens. JAMA. 2020. [epub, accessed: May 25, 2020]

[66] Rawson TM, Moore LSP, Zhu N, et al. Bacterial and fungal coinfection in individuals with coronavirus: A rapid review to support COVID-19 antimicrobial prescribing. Clin Infect Dis. 2020. [epub, accessed: May 25, 2020]

[67] Sepulveda J, Westblade LF, Whittier S, et al. Bacteremia and blood culture utilization during COVID-19 surge in New York City. J Clin Microbiol. 2020. [epub, accessed: May 25, 2020]

[68] Clancy CJ, Nguyen MH. COVID-19, superinfections and antimicrobial development: What can we expect? Clin Infect Dis. 2020 [epub, accessed: May 25, 2020]
[69] Huttner BD, Catho G, Pano-Pardo JR, et al. COVID-19: don't neglect antimicrobial stewardship principles! Clin Microbiol Infect. 2020. [epub, accessed: May 25, 2020]

[70] Koehler P, Cornely OA, Bottiger BW, et al. COVID-19 associated pulmonary aspergillosis. Mycoses. 2020. [epub, accessed: May 25, 2020]

[71] van Arkel A, Rijpstra T, Belderbos H, et al. COVID-19 Associated Pulmonary Aspergillosis. Am J Resp Crit Care Med. 2020. [epub, accessed: May 25, 2020]

[72] Antinori S, Bonazzetti C, Gubertini G, et al. Tocilizumab for cytokine storm syndrome in COVID-19 pneumonia: an increased risk for candidemia? Autoimmun Rev. 2020. [epub, accessed: May 25, 2020]

[73] Berlin DA, Gulick RM, Martinez FJ. Severe Covid-19. N Engl J Med. 2020. [epub, accessed: May 25, 2020]

[74] Gandhi RT, Lynch JB, Del Rio C. Mild or Moderate Covid-19. N Engl J Med. 2020. [epub, accessed: May 25, 2020]

[75] Tang N, Bai H, Chen X, et al. Anticoagulant treatment is associated with decreased mortality in severe coronavirus disease 2019 patients with coagulopathy. J Thromb Haemost. 2020; 18(5): 1094-1099.

[76] Levi M, Thachil J, Iba T, et al. Coagulation abnormalities and thrombosis in patients with COVID-19. Lancet Haematol. 2020. [epub, accessed: May 25, 2020]

[77] Klok FA, Kruip M, van der Meer NJM, et al. Incidence of thrombotic complications in critically ill ICU patients with COVID-19. Thromb Res. 2020. [epub, accessed: May 25, 2020]

[78] Bikdeli B, Madhavan MV, Jimenez D, et al. COVID-19 and thrombotic or thromboembolic disease: Implications for prevention, antithrombotic therapy, and follow-up. J Am Coll Cardiol. 2020. [epub, accessed: May 25, 2020]

[79] von Lilienfeld-Toal M, Vehreschild JJ, Cornely O, et al. Frequently asked questions regarding SARS-CoV-2 in cancer patients-recommendations for clinicians caring for patients with malignant diseases. Leukemia 2020. [epub, accessed: May 25, 2020]

[80] He W, Chen L, Chen L, et al. COVID-19 in persons with haematological cancers. Leukemia 2020. [epub, accessed: May 25, 2020]

[81] Baumann T, Delgado J, Montserrat E. CLL and COVID-19 at the Hospital Clinic of Barcelona: an interim report. Leukemia 2020. [epub, accessed: May 25, 2020]

[82] Li W, Wang D, Guo J, et al. COVID-19 in persons with chronic myeloid leukaemia. Leukemia 2020. [epub, accessed: May 25, 2020]

[83] Cook G, Ashcroft AJ, Pratt G, et al. Real-world assessment of the clinical impact of symptomatic infection with severe acute respiratory syndrome coronavirus (COVID-19 disease) in patients with Multiple Myeloma receiving systemic anti-cancer therapy. Br J Haematol. 2020. [epub, accessed: May 25, 2020]

[84] Guan WJ, Liang WH, Zhao Y, et al. Comorbidity and its impact on 1590 patients with COVID-19 in China: a nationwide analysis. Eur Respir J. 2020; 55(5): 1-13.

[85] Minotti C, Tirelli F, Barbieri E, et al. How is immunosuppressive status affecting children and adults in SARS-CoV-2 infection? A systematic review. J Infect. 2020. [epub, accessed: May 25, 2020]

[86] Liang W, Guan W, Chen R, et al. Cancer patients in SARS-CoV-2 infection: a nationwide analysis in China. Lancet Oncol. 2020. [epub, accessed: May 25, 2020]

[87] Pereira MR, Mohan S, Cohen DJ, et al. COVID-19 in solid organ transplant recipients: Initial report from the US epicenter. Am J Transplant. 2020. [epub, accessed: May 25, 2020]

A cikk a Creative Commons Attribution 4.0 International License (https://creativecommons.org/licenses/by/4.0/) feltételei szerint publikált Open Access közlemény, melynek szellemében a cikk bármilyen médiumban szabadon felhasználható, megosztható és újraközölhető, feltéve, hogy az eredeti szerző és a közlés helye, illetve a CC License linkje és az esetlegesen végrehajtott módosítások feltüntetésre kerülnek. (SID_1) 